\title{
THE REASONS AND EFFECTS OF THE LATE AGE OF MARRIAGE AMONG FEMALES IN THE CITY OF AJLOUN FROM THEIR POINT OF VIEW
}

\author{
AMNH AWAD FARHAN GHARAIBEH
}

Principle of the Amman Model School,Jordan

\begin{abstract}
This study aimed to identify the causes and effects of the late age of marriage among females in Jordan from their point of view, and used in this research the appropriate qualitative approach for the objectives of this research, which is the method that aims to describe the phenomenon as it is in reality and then analyze and explain and link it to other phenomena and reached the sample of research (8) girls who have not been married before, and the sample was chosen in the method of intent, and used the researcher in the collection of the questionnaire through the interview, and tried to answer the following questions What are the reasons for the delay in the age of marriage when females in Jordanian society are late? What are the social and psychological consequences of late marriage?

The study found that there are several reasons for the late age of marriage for girls, most notably: lack of convergence in the intellectual, educational and social level, different housing area, lack of acceptance of the parent of the applicant, the desire of the girl to complete her education, and the effects of delayed marriage age girls suffering from psychological and social problems concentrated by feelings of regret and psychological anxiety, the study showed that the appropriate age of marriage ranges from 24-28 years.
\end{abstract}

KEYWORDS: Marriage, Late Marriage

Received: Nov 08, 2020; Accepted: Nov 28, 2020; Published: Jan 08, 2021; Paper Id.: IJESRDEC20204

\section{INTRODUCTION}

God created creation and began the universe with Our Lord Adam (peace be upon him) and Mrs. Eve to continue breeding and reproduction to reconstruct the world and worship God. One of the most important blessings that God has harnessed for his creation is the bond of marriage to achieve tranquillity, stability and the formation of families. Marriage and the creation of a life partner are among the most important factors of survival and continuity, although marriage has different forms, methods, traditions and causes that vary according to persons, their motives, customs, traditions, needs, outlook and changing economic and social conditions over time.

Jordan has witnessed and continues to witness economic, social, demographic and technological change and a clear openness to the world that has been reflected in many aspects of people's lives, the most important of which is the subject of marriage and age at the age of marriage, while the problem of early marriage has been one of the problems that plagues Jordanian society in recent periods, as it has been noted that there is a clear rise in age at first marriage, especially among females, which confirms the phenomenon of delay in female marriage. In 1979, the average age at first marriage for females in Jordan was 21.1, in 1987 it was 24.3, 1999 was 25.5, and in 2012 it was 25.9 and 2019 (General Statistics Department, 1979, 199, 2012, 2019). The legal age of marriage in Jordan is (18) for both sexes according to the latest amendment to article (10) paragraph (a) of the Law: (Eligibility for marriage is 
required that the suitor and fiancée be reasonable and each has 18 solar years of his or her age). (Jordan's Personal Status Law, 2010). It is estimated that about 150,000 women were never married and were over 150,000 in 2015, 141,000 more than in 1979, and the figure doubled (22 times) from 1979 to the end of 2015. (Women's Statistics, Department of Public Statistics, (2015)

Despite this openness and development, there are still many established customs and traditions that pattern the image and status of women and their role in Jordanian society despite their reach to scientific, practical and social levels that are as important as those of men. The government's policy of "protecting the rights of women and children" is a key part of the government's efforts to address the problem of domestic violence. It should be noted that $40.8 \%$ of all single Jordanian women aged 20 years and over have a bachelor's degree in Jordan, depending on the educational situation. The proportion of single Jordanian females aged 20 and over working in multiple jobs (43.8\%) was also the same. The total number of females in Jordan is 1,000 , and the number of females in the country has been 12.5 per cent. (Women's Statistics, General Statistics Service, 2015).

\section{THEORETICAL LITERATURE}

Marriage, which is based on a healthy, true, generates true happiness, the male and female always feel that there is something that is permanently lacking and achieves their unity, except marriage, hence the basic need of every member of society, especially since the human being by marriage saves the human race from disappearing and guarantees continuity (Edward Mark: 2001, 285).

Previous studies have shown that marriage has changed in developing societies, after young men of both sexes were married at an early age, the tendency at present to delay the age of marriage has become either the result of the free choice of this delay, but as a result of the material conditions that are not favourable and the economic situation does not allow this, which prevents marriage at a time when young people want to get married, as confirmed by the study (Study of The Evil: 2008) in Saudi society to the first age of marriage He was between 13 and 34 years old, with an average age of 24 years for males and 22 years for females. The high proportion of married couples over the age of 25 is due to the fact that the young man has finished his studies and went to the labour market, and the study found that unemployment plays a major role in the late age of marriage due to the failure of the Saudi citizen to accept any job, which contributes to the delay of his marriage because of the inability to secure the living requirements and the costs of marriage.

In addition to adhering to the teachings of religion, the limited mixing between the sexes and the lack of material means to spend on the requirements of life, which helps to settle and form a family, all this confirms the importance of marriage, its necessity and the desire of the people, and their hope to achieve it. To delay the marriage after the lack of possibilities, and the inability to meet the requirements of marriage (Sana Kholi: 2002, 132).

This was confirmed by a study (Al-Khatatna, 2000) of the high cost of living and the low level of monthly income that prompts the young man to postpone his marriage for several years. The study also showed that continuing education is a factor that plays a role in delaying the age of marriage, as this means that a person who is still supported by his family is unable to decide to marry as long as he is not financially independent.

The study (Ali Hamdi bin Hussein: 2008) also confirmed that there is a great link to the reluctance of young people to marry, first and foremost: unemployment, lack of job opportunities, high cost of living, high cost of marriage, over-determination of some families in determining dowry, and not encouraging families to marry their children. 
One of the factors that lead to a young person's reluctance to marry is housing, and the resulting social and moral problems, because the inability to provide housing may lead to inability to marry, especially since a large proportion of girls require single housing to escape from the husband's family, especially the mother-in-law (Mohiuddin Abdel Hamid: 1995, 66).

This was confirmed by the study (Jalabana: 2017, 8) which confirmed that the economic conditions experienced by young people in Jordanian society made them delay their marriage, which consisted of a series of obstacles: low salaries, wages, high rent for apartments, and construction costs, Unemployment, lack of adequate employment opportunities, in addition to the fact that there are constraints related to the costs of marriage related to the economic conditions of young people, including: the high value of the dowry, which is not in line with the standard of living of families, the expenses after marriage, the high expenses of marriage, and the exaggeration of marriages, the study found Young people still have a traditional view of marriage, and the criteria adopted in choosing a partner in the sample are flexible, and the ceiling of conditions and demands is low.

The government's decision to amend the law to the general public is a matter of concern. (Karen Issued: 1996, 50)

This was confirmed by the study (Al-Jalabana: 2017,8) that there is a relationship between the girl's learning and her work outside the home on the one hand and the delayed age of her marriage on the other.

Study problem

Marriage is the first step in the formation of the family, which is the focus of building societies, and one of its noble objectives is to increase the human kind of the architecture of the universe and achieve tranquillity and satisfy the needs, so the delay in taking this step poses a threat to the basic needs of human beings, including females of course, according to the Pyramid of Maslow for human needs advocated by the psychologist Abraham Maslow.

Man has biological needs such as food, drink, clothing and sex, and is a communicator who cannot live in isolation from others and tends to be safe, stable, belonging and love to achieve himself and to be able to give, be able to achieve and creativity. It has been noted that this problem continues to grow in Jordanian society and has become more striking than ever, and if we look around the narrow society around us, we will note the presence of many single girls whose marriages have been delayed, regardless of the reasons behind it.

In the light of previous studies on some aspects of this study, it has been found to be important to focus or highlight other aspects overlooked by previous studies and to compare the change over time.

\section{THE IMPORTANCE OF STUDY}

The importance of the study stems from the fact that women in our society are considered marginalized groups in the light of the upbringing that promotes male power to men at the expense of women, which results in their submission to changing social and economic factors that limit their chances of marriage gradually, resulting in many psychological and social problems such as depression, isolation and moral decay, and has negative connotations, and social labels in each society.

This phenomenon in our society is becoming increasingly and increasing, as statistics show how much it is exacerbated among large groups of young people whose families are supposed to contribute to their emotional and sexual stability, make them productive elements, and its actors in the building of society, who find them emotionally and sexually unstable, living in a permanent societal contradiction between what their human nature demands and what society determines to satisfy it. 
The place of marriage in Jordanian society has made it the only indicator in the building of society, and the fundamental role socially recognized, surpassing the roles played by young people in society, especially the role of girls who are part of this society and an active actor in its permanence, society is institutional. His legislation and laws open the door for her to complete her education, enter the fields of work and may get higher ranks, but he returns, and holds her accountable for missing the chances of marriage before the thirty, while the man does not look at the same criteria, the male culture is dominant, The ruling on the subject punishes her and allows a man to marry a 20-year-old girl, who is 50 years of age, because he is able to have children at any age, unlike a girl who loses the opportunity to have children after that age (Galbana, 2017, 8).

\section{STUDY OBJECTIVES}

The study aimed at:

Identify the reasons why the age of marriage is delayed in females.

Identify psychological and social problems caused by the late age of marriage in females.

Learn about the attitudes of society and its view of the girl whose marriage is delayed -

\section{Study Questions:}

Through the researcher's experience of Jordanian society and the delay in the age of marriage for girls, this is indicated by previous statistics and studies and the researcher has wished to look into this phenomenon by answering the following questions:

What are the reasons for the late age of marriage for females in The City of Ajloun?

What are the psychological and social problems caused by the late age of marriage among females in The City of Ajloun?

What does society look at a girl whose marriage is delayed?

Study methodology:

\section{Curriculum}

The social survey method of the sample was used for the purposes of this study, referring to previous literature and studies that dealt with aspects related to this study as well as interviewing and observation.

\section{Study community:}

The study community consists of female researchers who have not yet married from the age of 35 and above in Ajloun.

\section{Sample study:}

A mean sample of seven females who had never been married was selected in Ajloun, and the sample is not accurately represented as a non-random sample and also small in size.

\section{Data collection tool}

The government has also established a national commission to provide as a basis for the development of the national education system. The questionnaire contained 46 closed and open questions closely related to the objectives of the study. 
Interview: Interview with (7) girls who have never been married aged 35 and over in the Kasbah Brigade, Ajloun governorate.

\section{Study limits:}

Spatial boundaries: This study was conducted in the city of Ajloun.

Temporal boundaries: This study was implemented in 20/10/2020 to 20/11/2020.

Demographic limits: This study was applied to a sample of unmarried girls aged 35 and over.

Study concepts:

- The government's efforts to address the problem of domestic violence are also being addressed. (Nasser Awad: 2001, 987)

It is also known that the age of marriage is delayed: as a denial of married life, the girl keeps waiting for the husband and does not come - and may come - but the illegal obstacles in the way of her marriage, she misses the train of marriage, and she continues to suffer from the anxiety of waiting and fear of the future, and fear of the plagues. (Mohammed al-Qadhi: 1998, 99)

Marriage as: a social system characterized by the uniqueness of continuity and compliance with social norms, which is the means by which society relies to regulate sexual issues, identify sexual issues, and determine the responsibility of images of sexual marriage among adults (Sana al-Kholi: 1981, 156).

\section{Study results}

The study reached a number of results in the light of the main objectives of the study, through the questionnaire, which was supported by the corresponding number of researchers and number edited by eight so that the following results were produced for each case:

\section{Case 1:}

A single girl between the ages of 40 and 44 with a secondary education, Muslim and living in a village with her family of three, including herself, works in a government job and supports her parents, her family's monthly income level ranges from 300 to less than 500 dinars. Marriage means stability, and she considers it essential in her life and one of her rights. You see that the age suitable for marriage is between 24 and 28 years. She has a desire to marry, but she does not plan her marriage and she is not the decision-maker on the subject of her marriage and considers it to be divided and shared by divorce. She has already submitted her engagement more than five times, but she refused to marry, and the most important reason for that refusal is that the applicants did not consider them of her intellectual, scientific or social level, nor did they enjoy the required external form, as she had rejected the way in which the suitors submitted the marriage and the reasons related to the family were the marriage of her younger brothers.

However, she believes that the criteria on which previous marriage proposals were rejected would not be the same if someone had proposed to her in the future. The researcher stressed that the delay in her marriage was a motive to complete her education and she prefers marriage to completing education, and she does not see her delay in marriage as a financial burden on her family, as she is the one who supports them financially and does not consider contributing to the family budget a barrier to her marriage, nor does she consider her economic independence to prevent her from marrying. 
She considers that the high cost of marriage in Jordan is one of the most important reasons for the delay in her marriage, and does not view the rise of her dowry as a sign of high value.

One of the problems she suffers as a result of delayed marriage is regret, sadness, vulnerability and sensitivity. As for the view of the society and those around her, she is not harassed by her family, but the treatment of her by her parents has become more sympathetic and she feels embarrassed by the intervention of others other than the family because she does not have the decision in her marriage, and she emphasizes that the society's view of marriage is different from what it was in the past due to changing living conditions.

\section{Case 2:}

A single girl over the age of 45 who has a diploma, a Muslim who lives in a village alone and her family members exceed 10 , including herself, works in a government job and supports one of her parents, her family's monthly income level ranges from 150- less than 300 dinars. Marriage means her participation, and she considers it a fundamental thing in her life and one of her rights. You see that the age suitable for marriage is between 24 and 28 years. She has a desire to marry and plans to marry, and she is the decision-maker on the subject of her marriage and considers it to be divided and shared by divorce. Her engagement has already been submitted twice and she did not refuse to marry, but because of the imposition of the opinion of others.

However, she believes that the criteria on which previous marriage proposals were rejected would not be the same if someone had proposed to her in the future. The researcher confirmed that the delay in her marriage was a motive to complete her education and she prefers marriage to completing education, and she does not see her delay in marriage as a financial burden on her family and does not consider contributing to the family budget a barrier to her marriage, nor does she consider her economic independence to make her a result from marriage. She considers that the high cost of marriage in Jordan is one of the most important reasons for the delay in her marriage, and does not view the rise of her dowry as a sign of high value.

The problems she suffers as a result of delayed marriage include regret, embarrassment, psychological anxiety, severe vulnerability, sensitivity, and a more propensity for worship and spirituality. As for the view of society and those around her, she is not harassed by her family, but the treatment of her by her parents has become more sympathetic and she feels that someone imposes his opinion on her, and she emphasizes that the society's view of marriage is different from what it was in the past, taking into account the cost of living.

\section{Case 3:}

A single girl between the ages of 40 and 44 with secondary education, a Muslim who lives in a village in her brother's house and has a family of more than a dozen, including herself, works in a private sector job and supports her brother because of his low salary, her family's monthly income level ranges from 150- under 300 dinars. Marriage is a sacred bond for her, and she considers her to be a fundamental thing in her life and a right. You see that the age suitable for marriage is between 24 and 28 years. She has a desire to marry and plans to marry, and she is the decision-maker on the subject of her marriage and considers it to be divided and shared by divorce. She has been engaged four times, and one of the reasons for this refusal is that one of the applicants was married before and also because of her emotional attachment to someone else.

However, she believes that the criteria on which previous marriage proposals were rejected would not be the same if someone had proposed to her in the future. She stressed that the delay in her marriage was not a motive to complete her 
education, that she did not prefer to marry in exchange for completing education, that she did not consider her delay in marriage to be a financial burden on her family, that contributing to the family budget was not a barrier to her marriage, nor did she consider her economic independence to be a result of marriage. She considers that the high cost of marriage in Jordan is one of the most important reasons for the delay in her marriage, and considers the rise of her dowry as a sign of high.

The problems she suffers as a result of delayed marriage include regret, sadness, embarrassment, depression, depression, extreme vulnerability, sensitivity, and a more propensity for worship and spirituality. As for the view of society and those around her, she is not harassed by her parents, who have become more sympathetic to her, but is treated with pressures from non-parents, such as offensive speech, and she refuses to do so, and she emphasizes that society's view of marriage is no different from what it was in the past with progress and development.

\section{Case 4:}

A single girl between the ages of 35 and 39 with a diploma, Muslim and living in a village with her family of 8-10, including herself, is not working and does not support anyone, her family's monthly income level ranges from 300 to less than 500 dinars. Marriage is a sacred bond aimed at creating a family, which she considers essential in her life and a right. You see that the age suitable for marriage is between 29 and 33 years. She has a desire to marry, but she does not plan her marriage and she is not the decision-maker on the subject of her marriage and considers it to be divided and shared by divorce. Her speech has already been submitted six times, but she has not been rejected each time.

However, she believes that the criteria on which previous marriage proposals were rejected would not be the same if someone had proposed to her in the future. The researcher stressed that the delay in her marriage was not a motive to complete her education and not to continue to learn is the reason for her delay and she does not prefer to marry in exchange for completing education, and she sees her delay in marriage as a financial burden on her family because she does not contribute to the family budget, nor does she consider her economic independence to spare her from marriage. She considers that the high cost of marriage in Jordan is one of the most important reasons for the delay in her marriage, and does not view the rise of her dowry as a sign of high value.

The problems she suffers as a result of delayed marriage include regret, sadness, embarrassment, depression, depression, depression and sensitivity. As for the view of society and those around her, she is not harassed by her family, but the treatment of her by her parents has become more cautious and she faces pressures from non-family, such as asking embarrassing questions about why she is not married and upset about it, as she emphasizes that society's view of marriage is different from what it was in the past with the tyranny of the modern lifestyle.

\section{Case 5:}

A single girl over the age of 45 who is a graduate student, Muslim and lives in a village with her family of three, including herself, working in a government job and supporting all family members, her family's monthly income level ranges from 300 to less than 500 dinars. Marriage for her is stable, and she considers it essential in her life and a right. You see that the appropriate age for marriage is between 19 and 23 years. She has a desire to marry and plans to do so, and she is the decision-maker on the subject of her marriage and considers it to be divided and shared by divorce. Her speech has already been submitted more than five times, but she has not been rejected each time. 
However, she believes that the criteria on which previous marriage proposals were rejected would not be the same if someone had proposed to her in the future. The researcher confirmed that the delay in her marriage was a motive to complete her education and she prefers to marry in exchange for completing education, and she does not see her delay in marriage as a financial burden on her family because she contributes to the family budget and that does not hinder her marriage, nor does she consider her economic independence to spare her from marriage. She considers that the high cost of marriage in Jordan is one of the most important reasons for the delay in her marriage, and does not view the rise of her dowry as a sign of high value.

The problems she suffers as a result of the delay of marriage include regret, sadness, embarrassment, psychological anxiety, depression, depression, vulnerability and sensitivity, and became more spiritual. As for the view of society and those around her, she is not harassed by her family or those around her, but the treatment of her by her parents has become more sympathetic and considers the intervention of others in the decision of her marriage is not their right, as she confirms that the society's view of marriage is different from what it was in the past, which it sees as becoming more complicated.

\section{Case 6:}

A single girl between the ages of 35 and 39 who is a Muslim and lives in a village with her family of 5-7, including herself, self-employed and supporting her sister who teaches at the university, her family's monthly income level ranges from 150 to less than 300 dinars. Marriage for her is stable, and she considers it essential in her life and a right. You see that the age suitable for marriage is between 24 and 28 years. She has a desire to marry and plans to do so, and she is the decisionmaker on the subject of her marriage and considers it to be divided and shared by divorce. Her engagement had already been submitted six times, but she was rejected because of the existence of moral qualities that were unacceptable to the applicant and rejected the way in which she was proposed to marry.

However, she believes that the criteria on which previous marriage proposals were rejected would not be the same if someone had proposed to her in the future. She also sees her late marriage as a financial burden on her family, even though she contributes to the family budget, but this contribution does not hinder her marriage at all, and she does not consider her economic independence to be a financial burden. She considers that the high cost of marriage in Jordan is one of the most important reasons for the delay in her marriage, and does not view the rise of her dowry as a sign of high value.

She does not suffer from any psychological or social problems as a result of the delay in her marriage, but she has become more inclined to spirituality and worship than before. As for the view of the society and those around her, she is not harassed by her family and their treatment has not changed at all, but she receives pressure from those around her other than the family, such as directing some talk to her about her delay in marriage and no one interfered in her marriage decision at all, as she emphasizes that the society's view of marriage is different from what it was in the past.

\section{Case 7:}

A single girl between the ages of 40 and 44 who is educated at a university, a Muslim who lives in a village with a family of ten or more, including herself, works in a government job and supports her mother, sisters and brothers, her family's monthly income of 150- less than 300 dinars. Marriage for her is stable, and she considers it a minor thing in her life and a right. You see that the age suitable for marriage is between 24 and 28 years. She has a desire to marry and plans to do so, and she is the decision-maker on the subject of her marriage and considers it to be divided and shared by divorce. Her 
engagement had already been submitted twice, but she refused because he was not from the same region and refused the way she applied for marriage, and because the parents did not accept the person she wanted to marry.

However, she believes that the criteria on which previous marriage proposals were rejected would not be the same if someone had proposed to her in the future. She also does not see her late marriage as a financial burden on her family, as she contributes to the family budget and this does not hinder her marriage at all, and she does not consider her economic independence to be a financial burden. She considers that the high cost of marriage in Jordan is not one of the reasons for her delay in marriage, and does not view the rise of her dowry as a sign of high value.

One of the problems that come with the delay of marriage is her feelings of remorse and nervousness. As for the view of society and those around it, they are not harassed either by their parents or from those around them, but the treatment of the parents has become more respectful and interesting. She is embarrassed by the interference of others in her marriage decision, and she asserts that society's view of marriage is different from what it used to be.

\section{DISCUSS RESULTS}

It is clear from this study that delayed marriage among females is still a problem that haunts many girls in Jordanian society and threatens their basic needs because the vast majority tend to want to marry and form a family, and it also produces many psychological and social effects that reflect their children negatively, as confirmed by previous studies,

The study reached the following conclusions:

- The vast majority of women respondents stated that marriage means stability and sacred bond, and that it is a fundamental and human right, which is divided and shared by divorce, and all of them, without exception, wish to marry. Some have the decision to marry, others are not, and not all of them are planning to get married.

- The vast majority consider that the age appropriate for marriage is between 24 and 28 years.

- The most important reasons for the late age of marriage as revealed by the study were the fact that the vast majority rejected the method in which marriage was submitted, the lack of convergence in the intellectual, social and educational level, the lack of external form required, the earlier marriage of the applicant, the fact that he was not in the area inhabited by the girl, or because he had unacceptable moral qualities, the parents' disapproval of the person the girl wished to marry, the emotional attachment to another person, or finally the marriage of the younger sister before the older sister.

- The vast majority confirmed that delayed marriage was a motive for completing education, as most of them hold a university degree, diploma or postgraduate degree. Most of them preferred to marry rather than complete education.

- All the researchers suffer from psychological and social problems, which are concentrated in feelings of regret, embarrassment, psychological anxiety, extreme vulnerability and sensitivity as a result of the delay in their marriage.

- There is no pressure from the parents due to the delay of marriage, as most of them stated that the treatment of them by the parents became more sympathetic and interesting, but the pressures mostly come from outside and cause embarrassment and take a rejection attitude towards this intervention.

- All the researches confirmed that society's view of marriage is different from what it was in the past in light of the high cost of living and openness in Jordan compared to previous years. 


\section{RECOMMENDATIONS}

Some of the most important recommendations of the study in the light of the results are:

- Repeat and continue studies on this problem to include as many girls as possible whose marriage is delayed for more credibility in circulating the results.

- The need to minimize the negative effects suffered by girls as a result of delayed marriage by helping them to create new opportunities and strengthen their role in society.

- Proposals

- Campaigning to gain support to reduce costs related to marriage at a national level.

- Conduct awareness workshops for young men and women on the importance of marriage and family preservation.

- The introduction of premarital counselling services on the social and psychological side, focusing on the importance of proper planning, appropriate decision-making and adaptation to changing social and economic conditions with regard to female marriage, should not be limited to premarital medical examinations only.

\section{REFERENCES}

1. .oualiette Mohamed, (2009) Reasons for the late age of marriage in Algerian society on a male sample in the metropolitan urban area, an unpublished master's thesis, Ben Youssef Ben Khada University of Algeria.

2. . Department of General Statistics (2015,2012,1979,1999,2008,2009).

3. Issued, Cadre (1996). Anusa is a female space, Syria, the range of culture and publishing.

4. Alian, Fatima (2004). The big woman's problem: celibacy and instinct. Riyadh: Randa Alian.

5. .Ali Hamdi, Bin Hussein: (2008). Factors of youth reluctance to marry and treat them from the perspective of Islamic education, unpublished master's thesis, Um al-Qura University, Saudi Arabia, Faculty of Education.

6. .ordan's Personal Status Law, Article 10, Paragraph (A), (2010).

7. .Balhan, Isa. Nasser, Fahd (2014) reasons for the delayed age of marriage according to the perceptions of a Kuwaiti and American sample. Educational Journal, Kuwait University, Year 28, p. 33-55

8. .Al-Jalbana, Mohammed (2017). A letter entitled The late age of marriage and its implications for the social relations between the sexes in Jordanian society, Amman is a model. Rabat, Mohammed V University, unpublished letter.

9. .Al-Khatatneh, Abdul Khaliq, (2000). Study entitled 'Late age of marriage among young males'. Yarmouk Research, Volume 16, Issue 1.

10. .Al-Kholi, Sana (2002), housing crisis and youth problems, University Knowledge House, Azarita.

11. .Al-Kholi, Sanaa, (1991). Marriage and family relationships. Alexandria: University Knowledge House.

12. .Al-Kholi, Sanaa, (1984). Family and family life. Beirut: Arab Renaissance House.

13. Al-Sharari, Abdullah, (2008). A field study entitled Age at first marriage in al-Jouf area. Al-Jouf, Saudi Arabia, unpublished letter.

14. .Mahdi, Lutfia, (2004). A letter entitled Neurotic Anxiety and its relation to the late marriage age of Yemeni women. Sana'a, unpublished letter. 
15. .Mark, The Roles of Duster (2001). Encyclopaedia of Delayed Marriage, translated by Misbah Samad et al., University Foundation for Studies, Publishing and Distribution.

16. .Mohiuddin, Abdel Hamid (1995). The spin-off between the harms and the treatment, the reality of the spin, Jeddah, the service of modern service.

17. .Michel, Duncan, (1986) Dictionary of Sociology, translated by Dr. Ihsan Mohammed Al Hassan, Beirut, Dar Al-Talaa printing and publishing.

Circle around the answers that apply most to you.

\begin{tabular}{|c|c|c|}
\hline Number & Qualitative data & \\
\hline 1. & Education: & $\begin{array}{l}\text { 1. Secondary 2. Diploma 3.University 4. Graduate } \\
\text { Studies }\end{array}$ \\
\hline 2. & Property: & 1. City 2. Village 3.Camp 4.Badia \\
\hline 3. & Number of family members including you: & $\begin{array}{l}\text { 1. 2-4 personnel 2. 5-7 personnel 3. 8-10 personnel } \\
\text { 4. } 10 \text { and over }\end{array}$ \\
\hline 4. & Do you live? & $\begin{array}{l}\text { 1. On your own } 2 \text {. With the family } 3 \text {. In the house of } \\
\text { brother } 4 \text {. In the house of sister } 5 \text {. In the house of } \\
\text { grandfather and grandmother } 6 . \text { Other } \\
\text { (select)................ }\end{array}$ \\
\hline 5. & Are you an employee? & 1.yes 2.No \\
\hline 6. & If the answer is yes, select the type of job: & $\begin{array}{l}\text { 1. Government 2. Private sector } 3 \text {. Free Business } \\
\text { 4.Otherwise, select........ }\end{array}$ \\
\hline 7. & $\begin{array}{l}\text { Are you supporting one or all of the family } \\
\text { members? }\end{array}$ & 1.yes 2.No \\
\hline 8. & If yes, (select from) & \\
\hline 9. & The monthly income of the family in dinars? & $\begin{array}{l}\text { 1.less than } 150 \text { dinars 2) } 150 \text { - less than } 300 \text { dinars } \\
\text { 3) } 300 \text { - less than } 500 \text { dinars 4) } 500 \text { dinars and more }\end{array}$ \\
\hline 10. & Age in years: & 1. 35-39 years $2.40-44$ years 3.45 years and older \\
\hline 11. & Religion: & 1. Muslim 2.Christian 3. Otherwise, Select..... \\
\hline \multicolumn{3}{|c|}{ Reasons for delayed marriage in females } \\
\hline \multicolumn{3}{|c|}{ What does marriage mean to you? } \\
\hline 12 & Do you look at marriage as? & $\begin{array}{l}\text { 1.Something essential in your life } \\
\text { 2. Something secondary in your life }\end{array}$ \\
\hline 13 & Do you think marriage & $\begin{array}{l}\text { 1. Your right 2. Duty you have to do } \\
\text { 3. Worldly Experience }\end{array}$ \\
\hline 14 & $\begin{array}{l}\text { What do you think is the right age for } \\
\text { marriage? }\end{array}$ & $\begin{array}{l}\text { 1.Under } 18 \\
2.19-23 \text { years old } \\
3.24-28 \text { years old } \\
4.33-29 \text { years old } \\
5.33 \text { years old }\end{array}$ \\
\hline 15 & Do you want to get married? & 1.yes 2.No \\
\hline 16 & If not, what are the reasons? & Select................... \\
\hline 17 & Are you planning on getting married? & 1.yes 2.No \\
\hline
\end{tabular}




\begin{tabular}{|c|c|c|}
\hline 18 & Are you a decision-maker on your marriage? & 1.yes 2.No \\
\hline 19 & $\begin{array}{l}\text { Do you think marriage is divided and shared } \\
\text { by divorce? }\end{array}$ & 1.yes 2.No \\
\hline 20 & Have you ever given up on your engagement? & 1.yes 2.No \\
\hline 21 & If yes, how many times has that happened? & $\begin{array}{l}\text { 1. Once 2.Twice 3. Otherwise } \\
\text { (select) }\end{array}$ \\
\hline 22 & Did you turn down the marriage proposal? & 1.yes 2. No \\
\hline 23 & If yes, what are your reasons for this? & $\begin{array}{l}\text { Choose one or more. } \\
\text { 1.It wasn't as high as my intellectual level. } \\
\text { 2.He wasn't close or at the same level of science. } \\
\text { 3.It wasn't at the social level. } \\
\text { 4.It doesn't have the external shape required. } \\
\text { 5.His salary is low. } \\
\text { 6. has no fixed source of income } \\
\text { 7.He's got a disease. } \\
\text { 8.He's got unacceptable moral qualities. } \\
\text { 9.Married before } \\
\text { 10.His age is not right. } \\
\text { 11.Other reasons (select).......... } \\
\text { (b) Special reasons for you? Choose one or more. } \\
\text { 1.Because of my desire to complete my education. } \\
\text { 2.Because I'm supporting my family or one of its } \\
\text { members. } \\
\text { 3.Because I'm a non-working girl. } \\
\text { 4.I refuse the way you propose to me. } \\
\text { 5.I'm emotionally attached to someone else. } \\
\text { 6.The trauma of a previous relationship ended in } \\
\text { failure. } \\
\text { 7.Because I'm not pretty. } \\
\text { 8.I'm afraid of what I've heard from failed } \\
\text { experiences like divorce and betrayal. } \\
\text { 9.I have a knot of the opposite sex. } \\
\text { 10.Other reasons (select............. } \\
\text { (c) Family and outdoor reasons: choose one or more } \\
\text { 1.Parents do not accept your choice of the person } \\
\text { you wished to marry. } \\
\text { 2.social custom that made my man's decision. } \\
\text { 3.The marriage of your younger brothers before you. } \\
\text { 4.Other reasons (select).......................... }\end{array}$ \\
\hline 24 & $\begin{array}{l}\text { Do you think that the criteria on which } \\
\text { previous marriage offers were rejected by you } \\
\text { would be the same if someone submitted your } \\
\text { engagement in the future? }\end{array}$ & 1.yes 2.No \\
\hline 25 & $\begin{array}{l}\text { Was your late marriage a motive to complete } \\
\text { your education? }\end{array}$ & 1.yes 2.No \\
\hline 26 & $\begin{array}{l}\text { Was continuing to complete education one of } \\
\text { the reasons for your late marriage? }\end{array}$ & 1.yes 2.No \\
\hline 27 & $\begin{array}{l}\text { Would you rather you got married and didn't } \\
\text { complete your education? }\end{array}$ & 1.yes 2.No \\
\hline 28 & $\begin{array}{l}\text { Do you think your late marriage is a financial } \\
\text { burden on your family? }\end{array}$ & 1.yes 2.No \\
\hline
\end{tabular}




\begin{tabular}{|c|c|c|}
\hline 29 & Do you contribute to the family budget? & 1.yes 2.No \\
\hline 30 & $\begin{array}{l}\text { If the answer is yes, does this contribution } \\
\text { prevent you from getting married? }\end{array}$ & 1.yes 2.No \\
\hline 31 & $\begin{array}{l}\text { Do you consider your work and economic } \\
\text { independence to make you a marriage? }\end{array}$ & 1.yes 2.No \\
\hline 32 & $\begin{array}{l}\text { Do you think that the high cost of marriage in } \\
\text { Jordan is one of the reasons for your delay? }\end{array}$ & 1.yes 2.No \\
\hline 33 & $\begin{array}{l}\text { Do you think your pony height is a sign of } \\
\text { your destiny? }\end{array}$ & 1.yes 2.No \\
\hline 34 & Problems caused by late marriage & 1.yes 2.No \\
\hline 35 & $\begin{array}{l}\text { Do you regret not accepting previous marriage } \\
\text { offers? }\end{array}$ & 1.yes 2.No \\
\hline 36 & $\begin{array}{l}\text { Do you feel low self-esteem because your } \\
\text { marriage is delayed? }\end{array}$ & 1.yes 2.No \\
\hline 37 & $\begin{array}{l}\text { Would you rather avoid talking about it } \\
\text { because it creates a feeling of sadness? }\end{array}$ & 1.yes 2.No \\
\hline 38 & Are you embarrassed by your late marriage? & 1.yes 2.No \\
\hline 39 & $\begin{array}{l}\text { Do you feel inferior because you're not } \\
\text { married yet? }\end{array}$ & 1.yes 2.No \\
\hline 40 & Does delayed marriage cause you to worry? & 1.yes 2.No \\
\hline 41 & Are you depressed by your late marriage? & 1.yes 2.No \\
\hline \multicolumn{3}{|c|}{ Have you become more inclined to worship and spirituality than ever before because of the delay in your marriage? } \\
\hline 42 & $\begin{array}{l}\text { Are you having one of the following problems } \\
\text { because of your late marriage? }\end{array}$ & $\begin{array}{l}\text { 1.Insomnia } \\
\text { 2.Nervousness } \\
\text { 3.Severity of vulnerability and sensitivity } \\
\text { 4.Retribution on the ocean } \\
\text { 5.Isolation } \\
\text { 6.Otherwise (select).............. }\end{array}$ \\
\hline \multicolumn{3}{|c|}{ Society's view of the girl whose marriage is delayed. } \\
\hline 43 & $\begin{array}{l}\text { Are you being harassed by your family } \\
\text { because you haven't married yet? }\end{array}$ & 1.yes 2.No \\
\hline 44 & $\begin{array}{l}\text { Are you facing pressure from non-family } \\
\text { members as a result of your late marriage? }\end{array}$ & 1.yes 2.No \\
\hline 45 & If yes, what are these pressures? & Select.............. \\
\hline 46 & Have you become treated by parents? & 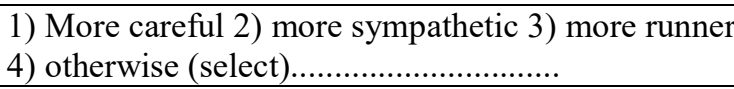 \\
\hline
\end{tabular}



